\title{
Tropical continental downdraft characteristics: mesoscale systems versus unorganized convection
}

\author{
Kathleen A. Schiro and J. David Neelin \\ Department of Atmospheric and Oceanic Sciences, University of California Los Angeles, Los Angeles, CA, USA
}

Correspondence: Kathleen A. Schiro (kschiro@atmos.ucla.edu)

Received: 21 July 2017 - Discussion started: 28 August 2017

Revised: 19 December 2017 - Accepted: 20 December 2017 - Published: 12 February 2018

\begin{abstract}
Downdrafts and cold pool characteristics for strong mesoscale convective systems (MCSs) and isolated, unorganized deep precipitating convection are analyzed using multi-instrument data from the DOE Atmospheric Radiation Measurement (ARM) GoAmazon2014/5 campaign. Increases in column water vapor (CWV) are observed leading convection, with higher CWV preceding MCSs than for isolated cells. For both MCSs and isolated cells, increases in wind speed, decreases in surface moisture and temperature, and increases in relative humidity occur coincidentally with system passages. Composites of vertical velocity data and radar reflectivity from a radar wind profiler show that the downdrafts associated with the sharpest decreases in surface equivalent potential temperature $\left(\theta_{\mathrm{e}}\right)$ have a probability of occurrence that increases with decreasing height below the freezing level. Both MCSs and unorganized convection show similar mean downdraft magnitudes and probabilities with height. Mixing computations suggest that, on average, air originating at heights greater than $3 \mathrm{~km}$ must undergo substantial mixing, particularly in the case of isolated cells, to match the observed cold pool $\theta_{\mathrm{e}}$, implying a low typical origin level. Precipitation conditionally averaged on decreases in surface equivalent potential temperature $\left(\Delta \theta_{\mathrm{e}}\right)$ exhibits a strong relationship because the most negative $\Delta \theta_{\mathrm{e}}$ values are associated with a high probability of precipitation. The more physically motivated conditional average of $\Delta \theta_{\mathrm{e}}$ on precipitation shows that decreases in $\theta_{\mathrm{e}}$ level off with increasing precipitation rate, bounded by the maximum difference between surface $\theta_{\mathrm{e}}$ and its minimum in the profile aloft. Robustness of these statistics observed across scales and regions suggests their potential use as model diagnostic tools for the improvement of downdraft parameterizations in climate models.
\end{abstract}

\section{Introduction}

Convective downdrafts involve complex interactions between dynamics, thermodynamics, and microphysics across scales. They form cold pools, which are evaporatively cooled areas of downdraft air that spread horizontally and can initiate convection at their leading edge (Byers and Braham, 1949; Purdom, 1976; Wilson and Schreiber, 1986; Rotunno et al., 1988; Fovell and Tan, 1998; Tompkins, 2001; Khairoutdinov and Randall, 2006; Lima and Wilson, 2008; Khairoutdinov et al., 2009; Böing et al., 2012; Rowe and Houze, 2015). The boundary between the cold pool and the surrounding environmental air, known as the outflow boundary or gust front, is key to sustaining multi-cellular deep convection (e.g., Weisman and Klemp, 1986). It has also been shown to trigger new convective cells in marine stratocumulus (Wang and Feingold, 2009; Terai and Wood, 2013) and trade-wind cumulus clouds (Zuidema et al., 2012; Li et al., 2014). Downdrafts also have implications for new particle formation in the outflow regions, which contribute to maintaining boundary layer cloud condensation nuclei $(\mathrm{CCN})$ concentrations in unpolluted environments (Wang et al., 2016).

Precipitation-driven downdrafts are primarily a result of condensate loading and the evaporation of hydrometeors in unsaturated air below cloud base (e.g., Houze, 1993), with evaporation thought to be the main driver (Knupp and Cotton, 1985; Srivastava, 1987). It was originally suggested by Zipser (1977) that the downdrafts in the convective part of a system, referred to in the literature as convective-scale downdrafts, are saturated, and that the downdrafts in the trailing stratiform region (referred to as mesoscale downdrafts) are unsaturated. Studies with large-eddy simulations (LES; Hohenegger and Bretherton, 2011; Torri and Kuang, 2016) in- 
dicate, however, that most convective downdrafts are unsaturated, consistent with evidence that the evaporation of raindrops within the downdraft likely does not occur at a sufficient rate to maintain saturation (Kamburova and Ludlam, 1966).

More recently, studies have shown the importance of downdraft parameters in maintaining an accurate simulation of tropical climate in global climate models (GCMs; Maloney and Hartmann, 2001; Sahany and Nanjundiah, 2008; Del Genio et al., 2012; Langenbrunner and Neelin, 2018). Accurate simulation of mesoscale convective systems (MCSs) in continental regions (Pritchard et al., 2011) was also shown to be sensitive to downdraft-boundary layer interactions, with significantly improved representation of MCS propagation in the central USA once such interactions were resolved. Additionally, representing the effects of downdrafts and cold pools in models has been shown to have positive effects on the representation of the diurnal cycle of precipitation (Rio et al., 2009; Schlemmer and Hohenegger, 2014).

This study aims to characterize downdrafts in a comprehensive way in the Amazon for both isolated and mesoscale convective systems, and to provide useful guidance for downdraft parameterization in GCMs. Data from the DOEBrazil Green Ocean Amazon (GoAmazon) campaign (20142015; Martin et al., 2016) provide an unprecedented opportunity to evaluate downdraft characteristics in the Amazon with sufficiently large data sets for quantifying robust statistical relationships describing leading order processes for the first time. Relationships explored previously, primarily in tropical oceanic (Barnes and Garstang, 1982; Feng et al., 2015; de Szoke et al., 2017) or mid-latitude regions (Charba, 1974; Engerer et al., 2008), such as time composites of wind and thermodynamic quantities relative to downdraft precipitation, are also revisited and compared to our findings over the Amazon. Downdrafts in MCSs and isolated cells are compared to inform decisions concerning their unified or separate treatment in next generation models. The effect of downdrafts on surface thermodynamics and boundary layer recovery are examined, and the origin height of the downdrafts is explored, combining inferences from radar wind profiler data for vertical velocity and thermodynamic arguments from simple plume models. Lastly, statistics describing cold pool characteristics at the surface are presented and discussed for possible use as model diagnostics.

\section{Data and methods}

Surface meteorological values (humidity, temperature, wind speed, precipitation) were obtained from the Aerosol Observing System Surface Meteorology station (AOSMET; Atmospheric Radiation Measurement Climate Research Facility, 2013a) at the DOE ARM site in Manacapuru, Brazil, established as part of the GoAmazon2014/5 campaign. The record used in this study spans 10 January 2014-20 October
2015. Equivalent potential temperature is computed following Bolton (1980).

Thermodynamic profiles are obtained from radiosonde measurements (Atmospheric Radiation Measurement Climate Research Facility, 2013b) within 6 h of a convective event. Radiosondes are launched at approximately 01:30, 07:30, 13:30, and 19:30 local time (LT) each day, with occasional radiosondes at 10:30 LT in the wet season. Profiles of vertical velocity and radar reflectivity are obtained from a $1290 \mathrm{MHz}$ radar wind profiler (RWP) reconfigured for precipitation modes (Atmospheric Radiation Measurement Climate Research Facility, 2015). The RWP has a beam width of $6^{\circ}(\sim 1 \mathrm{~km}$ at $10 \mathrm{~km}$ a.g.1.), a vertical resolution of $200 \mathrm{~m}$, and a temporal resolution of $6 \mathrm{~s}$ (see also Giangrande et al., 2016).

Precipitation data at 25 and $100 \mathrm{~km}$, as well as convection classifications, are derived from an $S$-band radar located approximately $67 \mathrm{~km}$ to the northeast of the primary GoAmazon2014/5 site (T3) at the Manaus Airport (Atmospheric Radiation Measurement Climate Research Campaign Data, 2015). Composite constant altitude low-level gridded reflectivity maps (constant altitude plan position indicators, CAPPIs) were generated, and the radar data were gridded to a Cartesian coordinate grid with horizontal and vertical resolution of 2 and $0.5 \mathrm{~km}$, respectively. Rain rates were obtained from the $2.5 \mathrm{~km}$ reflectivity using the reflectivity-rain rate $(Z-R)$ relation $Z=174.8 R^{1.56}$ derived from disdrometer data. The spatially averaged rainfall rates over 25 and $100 \mathrm{~km}$ grid boxes surrounding the GoAmazon site were used in this study. The center of the $100 \mathrm{~km}$ grid box is shifted slightly to the right of center with respect to the T3 site due to reduced data quality beyond a $110 \mathrm{~km}$ radius.

Every downdraft associated with either MCSs or isolated cells that created a subsequent drop in $\theta_{\mathrm{e}}$ at the surface of more than $5 \mathrm{~K}$ in a $30 \mathrm{~min}$ period and have precipitation rates exceeding $10 \mathrm{~mm} \mathrm{~h}^{-1}$ within that same period are composited. These criteria were chosen to examine the most intense downdraft events with the most well-defined vertical velocity signatures in the RWP data. Only data for events with complete vertical velocity data coverage over the $1 \mathrm{~h}$ period spanning the passage of the convective cells and centered around the maximum precipitation were composited and evaluated.

Isolated convective cells were identified by $S$-band composite reflectivity, as in Fig. 1, and are defined as being less than $50 \mathrm{~km}$ in any horizontal dimension (contiguous pixels with reflectivity $>30 \mathrm{dBZ}$ ) with a maximum composite reflectivity of greater than or equal to $45 \mathrm{dBZ}$. Following the criteria defined above, this resulted in the selection of 11 events, all of which were in the late morning or afternoon hours between 11:00 and 18:00 LT. Mesoscale convective systems follow the traditional definition of regions of contiguous precipitation at scales of $100 \mathrm{~km}$ or greater (contiguous pixels with reflectivity $>30 \mathrm{dBZ}$ ) in any horizontal dimension (e.g., Houze, 1993, 2004). All of the events sampled are characterized by a leading edge of convective cells 

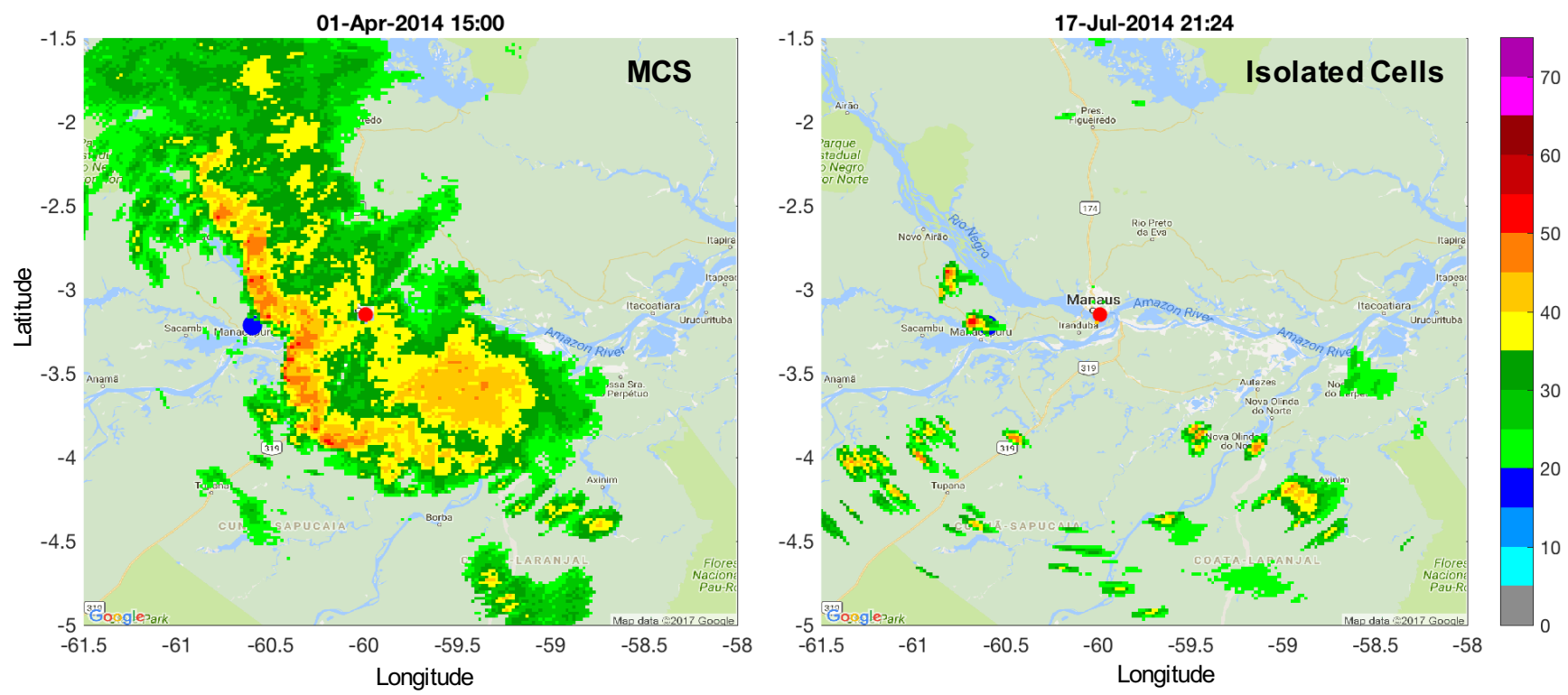

Figure 1. Reflectivity (dBZ) from S-band radar on 1 April 2014 at 15:00 UTC (11:00 LT) before the passage of an MCS, and at 17 July 2017 at 21:24 UTC (17:24 LT) after the passage of an isolated cell. The red dot indicates the location of the $S$-band radar, and the blue dot indicates the location of the main GoAmazon site (T3).

with a trailing stratiform region (Fig. 1), which is the most common MCS type (Houze et al., 1990). The above criteria yielded 18 events: 12 in the late morning and early afternoon hours (11:00-18:00 LT) and 6 in the late evening/early morning hours (22:00-11:00 LT).

In Sect. 6, statistics are presented using nearly the entire 2-year time series of meteorological variables at the GoAmazon2014/5 site, as well as 15 years of data (1996-2010) from the DOE ARM site at Manus Island in the tropical western Pacific. One-hour averages are computed in $\Delta \theta_{\mathrm{e}}$ and precipitation.

\section{Surface thermodynamics}

Composites of surface meteorological variables are displayed in Fig. 2 for the 11 isolated cellular deep convective events coinciding with drops in equivalent potential temperature of $5 \mathrm{~K}$ or greater and precipitation rates greater than $10 \mathrm{~mm} \mathrm{~h}^{-1}$ (see Sect. 2). The composites are centered $3 \mathrm{~h}$ before and after the $5 \mathrm{~min}$ interval marking the sharpest decrease in surface $\theta_{\mathrm{e}}$ in the mean time series (time 0 ). All time series averaged in the composites are shifted to the mean value at the $\theta_{\mathrm{e}}$ minimum and shading on the composites shows \pm 1 standard deviation for anomalies with respect to the $\theta_{\mathrm{e}}$ minimum to provide a sense of the variability. All differences quoted are the differences between the maximum and minimum values within the $1 \mathrm{~h}$ time frame of convective cell passage ( \pm 30 min of time 0$)$, unless noted otherwise. Recovery percentages are computed as the difference between the minimum and maximum values between time 0 and some specified time afterwards, divided by the difference between the minimum and maximum values within $30 \mathrm{~min}$ of time 0 .

In the $2 \mathrm{~h}$ leading isolated convection, the column water vapor $(\mathrm{CWV})$ increases by $4.5 \mathrm{~mm}$. The mean value of $\theta_{\mathrm{e}}$ $30 \mathrm{~min}$ before the minimum recorded $\theta_{\mathrm{e}}$ is $353.7 \mathrm{~K}$. As the systems pass, the $\theta_{\mathrm{e}}$ mean value drops by an average $9.6 \mathrm{~K}$ to an average value of $344.2 \mathrm{~K}$. Since the isolated convective cells observed occur in the daytime hours, the relative humidity is seen to drop steadily throughout the $3 \mathrm{~h}$ period leading the convection following the rise in temperatures with the diurnal cycle. The mean relative humidity $(\mathrm{RH})$ rises to $82.3 \%$ within $30 \mathrm{~min}$ of system passage, which indicates that the downdrafts are sub-saturated when they reach the surface. Within the hour, temperatures drop by 4.2 to $24.7 \mathrm{~K}$, which is a smaller decrease than observed over mid-latitude sites (see Table 2 in Engerer et al., 2008, for a review of mid-latitude case studies) and specific humidity drops by 1.5 to $15.7 \mathrm{~g} \mathrm{~kg}^{-1}$. Mean winds reach $6.4 \mathrm{~m} \mathrm{~s}^{-1}$, consistent with previous studies that document strong horizontal winds associated with the leading edges of cold pools (e.g., Fujita, 1963; Wakimoto, 1982), but are lower than the observed values for mid-latitude storms (Engerer et al., 2008). Additionally, surface pressure often increases with the existence of a cold pool and is referred to as the meso-high (Wakimoto, 1982). Here, it increases marginally by $0.6 \mathrm{hPa}$, but this value is much less than the typical values observed in mid-latitudes (e.g., Goff, 1976; Engerer et al., 2008). Lastly, $32.7 \%$ (52.4\%) of the temperature and $88.8 \%(88.9 \%)$ moisture depleted by the downdraft recovers within $1 \mathrm{~h}(2 \mathrm{~h})$ of cell passage, with moisture recovering more quickly and by a greater percentage than temperature. It is likely that moisture recovers more 

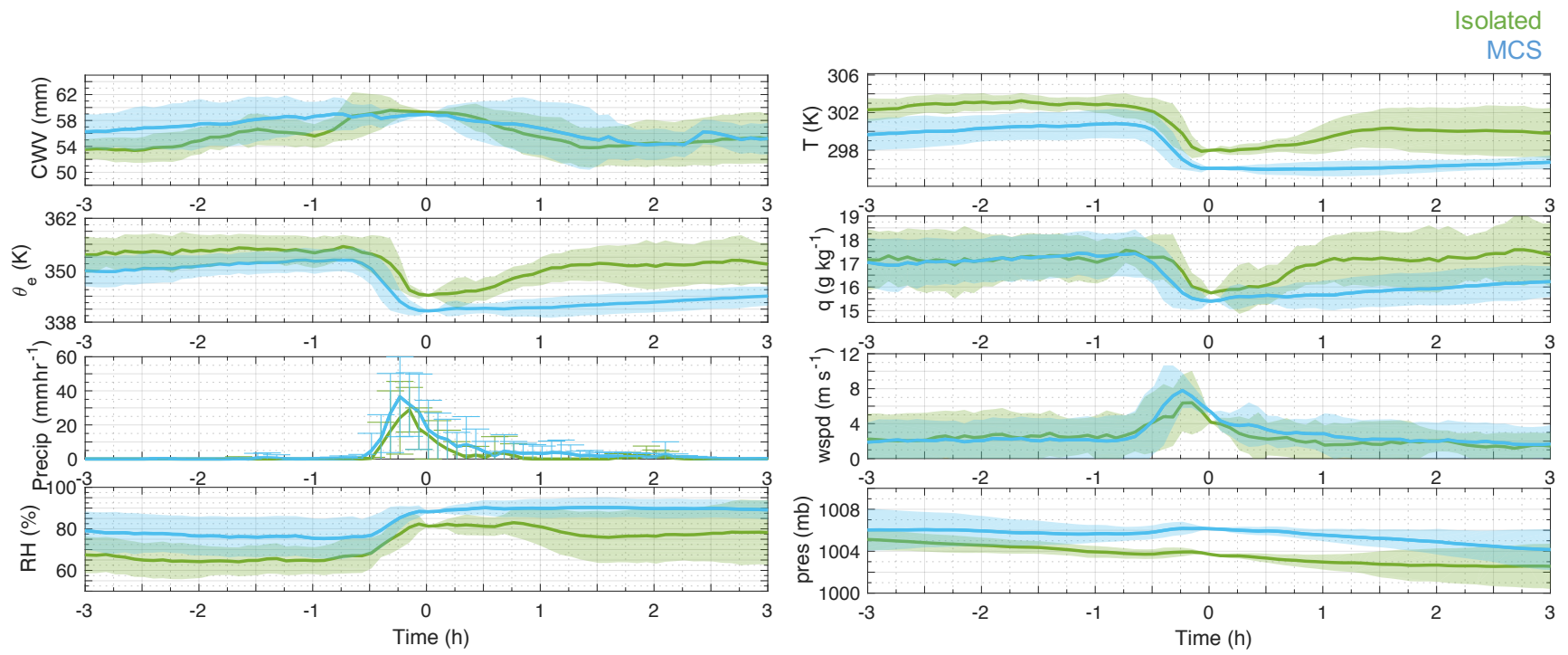

Figure 2. Composites of meteorological variables from the AOSMET station at site $\mathrm{T} 33 \mathrm{~h}$ leading and $3 \mathrm{~h}$ lagging the minimum in equivalent potential temperature $(0 \mathrm{~h}$; second panel) coincident with the passage of isolated cells (green) and MCSs (blue). Shading denotes \pm 1 standard deviation of anomalies with respect to $0 \mathrm{~h}$; bars on precipitation are \pm 1 standard deviation for each time interval. Standard errors would be smaller by a factor of 0.3 for isolated cells and 0.2 for MCSs.

quickly than temperature because of increased evaporation, while cloud cover persistence may continue to affect temperature. It is difficult to observe heat fluxes using eddy covariance techniques during precipitation, however, so we are unable to properly quantify this. Nevertheless, we include measurements of heat fluxes (Atmospheric Radiation Measurement Climate Research Facility, 2014) in Supplement Figs. S1 and S2 to assess general trends.

Composites of surface meteorological variables are also shown in Fig. 2 for the 18 MCSs with surface $\theta_{\mathrm{e}}$ depressions of $5 \mathrm{~K}$ or greater and coincident precipitation rates of $10 \mathrm{~mm} \mathrm{~h}^{-1}$ or greater. On average, the environment is more humid for MCSs than for the isolated cases, as is seen in the $\mathrm{CWV}$ composite. CWV between 1 and $3 \mathrm{~h}$ leading the MCSs is higher on average than that observed leading the isolated cells, but increases to a comparable magnitude of $\sim 59 \mathrm{~mm}$ within the hour. CWV increases by an average of $1.5 \mathrm{~mm}$ in the $2 \mathrm{~h}$ leading the passage of MCSs, which is slightly less than the increases reported in Taylor et al. (2017) $(\sim 4 \mathrm{~mm})$ in the Sahel, though the Amazon is a more humid environment. Values of $\theta_{\mathrm{e}}$ leading the passage of MCSs $(350.3 \mathrm{~K})$ are $3.4 \mathrm{~K}$ lower than the $\theta_{\mathrm{e}}$ values leading the isolated cells $(353.7 \mathrm{~K})$, mostly due to lower surface temperatures $(27.0 \mathrm{~K}$ for MCSs vs. $28.9 \mathrm{~K}$ for isolated cells). The precipitation occurs over a longer period than in the cases of isolated cells, as there is often stratiform rain trailing the leading convective cells. The stratiform rain and associated downdrafts also sustain the cooling and drying of the near-surface layers for many hours lagging the precipitation maximum. The relative humidity maximum in the cold pool is $90.2 \%(\Delta$ $\mathrm{RH}=13.3 \%)$, the specific humidity minimum is $15.4 \mathrm{~g} \mathrm{~kg}^{-1}$
$\left(\Delta q=1.6 \mathrm{~g} \mathrm{~kg}^{-1}\right)$, and the temperature minimum is $22.8 \mathrm{~K}$ $(\Delta T=4.2 \mathrm{~K})$, with winds gusting to an average of $7.8 \mathrm{~m} \mathrm{~s}^{-1}$ with the passage of the leading convective cells. The cold pools are thus cooler, drier, and nearer to saturation for the MCSs than for the isolated cells. It is worth noting that these statistics for MCSs are not greatly affected by the inclusion of nighttime events; composites for afternoon only MCSs yield similar results. Overall, on average, the environments in which MCSs live are moister, they have colder, drier cold pools that are nearer to saturation, the winds at their leading edges are gustier, and the boundary layer recovers more slowly than for isolated cells.

Here, we composite events based on strict criteria identifying the strongest convective events (see Table S1 in the Supplement for dates/times of events composited in Figs. 26). In Figs. $S 1$ and $S 2$, we instead composite based on either a minimum $\theta_{\mathrm{e}}$ decrease or a minimum precipitation rate to test the sensitivity of the results presented here and include additional events. We also examine the sensitivity to averaging by compositing time series of meteorological variables averaged at $30 \mathrm{~min}$ intervals and plot results for $6 \mathrm{~h}$ leading and lagging the convection. The features discussed above associated with the passage of isolated systems and MCSs are generally robust to averaging and the choice of imposed criteria.

\section{Downdraft origin and the effects of mixing}

Many previous studies of moist convective processes use $\theta_{\mathrm{e}}$ as a tracer since it is conserved in the condensation and evap- 
oration of water and for dry and moist adiabatic processes (e.g., Emanuel, 1994). Tracing surface $\theta_{\mathrm{e}}$ to its corresponding value aloft has been used in many studies of tropical convection to examine potential downdraft origin heights (e.g., Zipser, 1969; Betts, 1973, 1976; Betts and Silva Dias, 1979; Betts et al., 2002). This assumes that downdraft air conserves $\theta_{\mathrm{e}}$ to a good approximation and that downdraft air originates at one height above ground level. Neither of these assumptions is likely to be true, as mixing is likely occurring between the descending air and the environmental air and thus originating from various levels. However, it can provide a useful reference point for further considerations.

We examine the mean $\theta_{\mathrm{e}}$ profiles to place bounds on mixing and downdraft origin with simple thermodynamic arguments and plume computations. The profiles composited in Fig. 3 were measured within the $6 \mathrm{~h}$ prior to the same MCSs and isolated events composited in Fig. 2, less two MCS events that did not have corresponding radiosonde measurements. Simply matching the mean of the minimum $\theta_{\mathrm{e}}$ value within the cold pools to the minimum altitude at which those values are observed yields $2.1 \mathrm{~km}$ for MCSs (left panel, Fig. 3) and $1.5 \mathrm{~km}$ for isolated cells (right panel, Fig. 3). Again, this assumes that $\theta_{\mathrm{e}}$ is conserved and that the air originates at one altitude. If instead we assume that substantial mixing occurs with the surrounding environment and that air originates at multiple levels in the lower troposphere, it would be plausible for more of the air reaching the surface to originate at altitudes greater than 1.5 and $2.1 \mathrm{~km}$ for isolated cells and MCSs, respectively. This has been alluded to in previous studies (e.g., Zipser, 1969; Gerken et al., 2016), which provide evidence that air originates in the middle troposphere.

To examine this, we mix air from above the altitude where the $\theta_{\mathrm{e}}$ matched the surface value (shown in the composites in Fig. 2) downward towards the surface, varying the entrainment rate (constant in pressure coordinates). To start, we use a mixing of $0.001 \mathrm{hPa}^{-1}$, as this is the constant entrainment value used in Brown and Zhang (1997) and Holloway and Neelin (2009), which can produce realistic updraft buoyancy profiles over tropical oceans given simplified assumptions about freezing (no freezing) and condensate loading (all condensate retained). For the MCS case, it is plausible that a downdraft could originate at a height of $2.5 \mathrm{~km}$ given this rate of mixing to reach the surface with characteristics given by Fig. 2. If instead the air were to come from the level of minimum $\theta_{\mathrm{e}}(\geq 3.2 \mathrm{~km}$, on average), an assumption similar to that made by many downdraft parameterizations (e.g., Zhang and McFarlane, 1995; Tiedtke, 1989; Kain and Fritsch, 1990), mixing would need to be 2 times greater. For the isolated cells, mixing rates appear to need to be greater in order to produce results consistent with cold pool characteristics at the surface. If we start out at $0.002 \mathrm{hPa}^{-1}$, the rate sufficient for a minimum $\theta_{\mathrm{e}}$ origin for the MCSs, this only yields an origin height of $1.7 \mathrm{~km}$. If instead we assume the air originates somewhere near the level of minimum $\theta_{\mathrm{e}}$, mixing would need to be at least $0.004 \mathrm{hPa}^{-1}$. For simplicity, the discussion above is in terms of mean profiles - the standard error of the profiles is shown at 50 mbar intervals - but computation based on individual profiles yields a standard error in the inferred mixing of about $0.0005 \mathrm{hPa}^{-1}$. For reference, in the European Centre for Medium-Range Weather Forecasts Integrated Forecasting System (ECMWF IFS) and Goddard Institute for Space Studies (GISS) Model E2 GCM (Kim et al., 2011), downdrafts mix at a rate of $2 \times 10^{-4} \mathrm{~m}^{-1}$ (roughly equivalent to $0.002 \mathrm{hPa}^{-1}$ in pressure coordinates in the lower troposphere).

To summarize, this analysis is suggestive of bounds on mixing coefficients for downdraft parameterizations. If downdrafts of both convective types mix at similar rates, these results suggest that downdrafts from isolated cells originate at lower levels than MCSs, on average. If instead downdrafts originate from the level of minimum $\theta_{\mathrm{e}}$, mixing rates of 0.002 for MCSs and $0.004 \mathrm{hPa}^{-1}$ for isolated convection would be consistent with mean thermodynamic conditions. In Sects. 5 and 6, we provide a complementary probabilistic perspective on levels of origin.

\section{Vertical velocity and downdraft probability}

Figure 4 composites reflectivity $(Z)$, vertical velocity $(w)$, and the probability of observing downdrafts $\left(w<0 \mathrm{~m} \mathrm{~s}^{-1}\right)$ for the 11 cases of isolated cellular convection meeting the minimum $\Delta \theta_{\mathrm{e}}$ criteria of $-5 \mathrm{~K}$ and minimum precipitation criteria of $10 \mathrm{~mm} \mathrm{~h}^{-1}$. Time 0 is the time right before the sharpest decrease in $\theta_{\mathrm{e}}$ and maximum precipitation (slightly offset from the composites in Fig. 2). A $3 \mathrm{~h}$ window is composited for reference, but the interval of primary interest is the $1 \mathrm{~h}$ window within which the minimum $\Delta \theta_{\mathrm{e}}$ and maximum precipitation are observed. To highlight the interval of interest, the $1 \mathrm{~h}$ intervals leading and lagging this period are masked out.

The drop in $\theta_{\mathrm{e}}$ is coincident with the passage of the isolated cell and its main updraft and precipitation-driven downdraft. Mean reflectivity exceeding $40 \mathrm{dBZ}$ is observed during this period, as are strong updrafts in the middle-upper troposphere. The cell then dissipates and/or moves past the site within an hour. A downdraft is observed directly below and slightly trailing the updraft core. This is the downdraft that is associated with the largest drop in surface $\theta_{\mathrm{e}}$. As is suggested in the literature, these are mainly driven by condensate loading and evaporation of precipitation and are negatively buoyant. The probability of observing negative vertical velocity (threshold $<0 \mathrm{~m} \mathrm{~s}^{-1}$ ) within the 30 min of minimum $\Delta \theta_{\mathrm{e}}$ and maximum precipitation is highest in the lower troposphere (0-2 km), consistent with precipitation-driven downdrafts observed in other studies (Sun et al., 1993; Cifelli and Rutledge, 1994).

There is also a high probability of downdrafts in air near the freezing level (masked out in the vertical velocity re- 

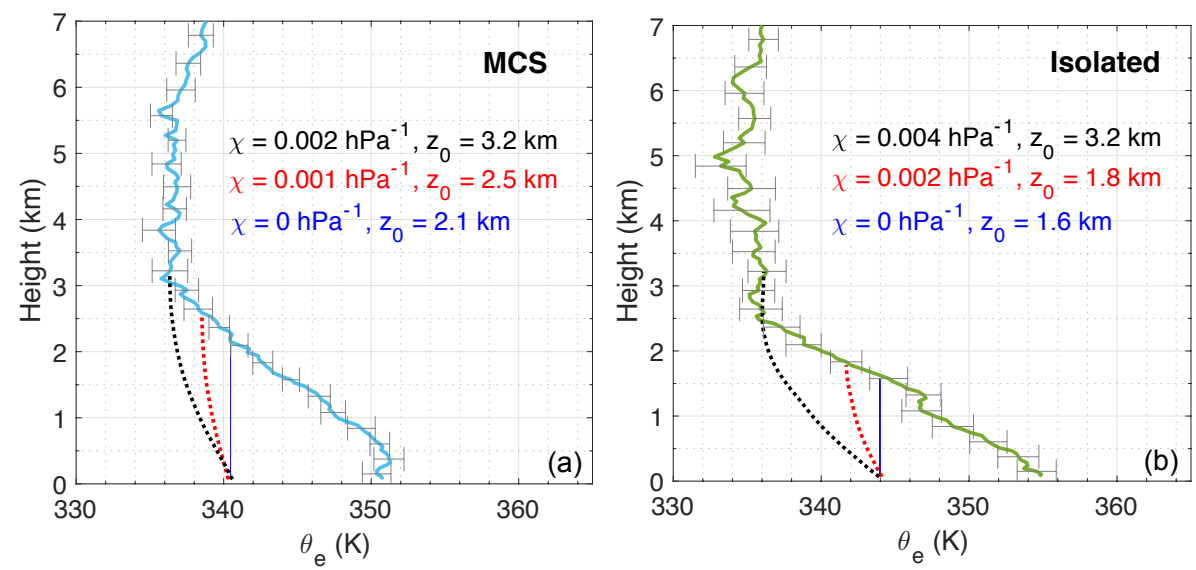

Figure 3. Mean profiles of $\theta_{\mathrm{e}}$ within $6 \mathrm{~h}$ leading the passage of a deep convective event for MCSs (16 profiles; a) and isolated cells (11 profiles; b). Dashed lines indicate the mean descent path for plumes originating at various altitudes and mixing with the environment at various rates; solid blue line shows mean descent without mixing. Error bars are \pm 1 standard error.
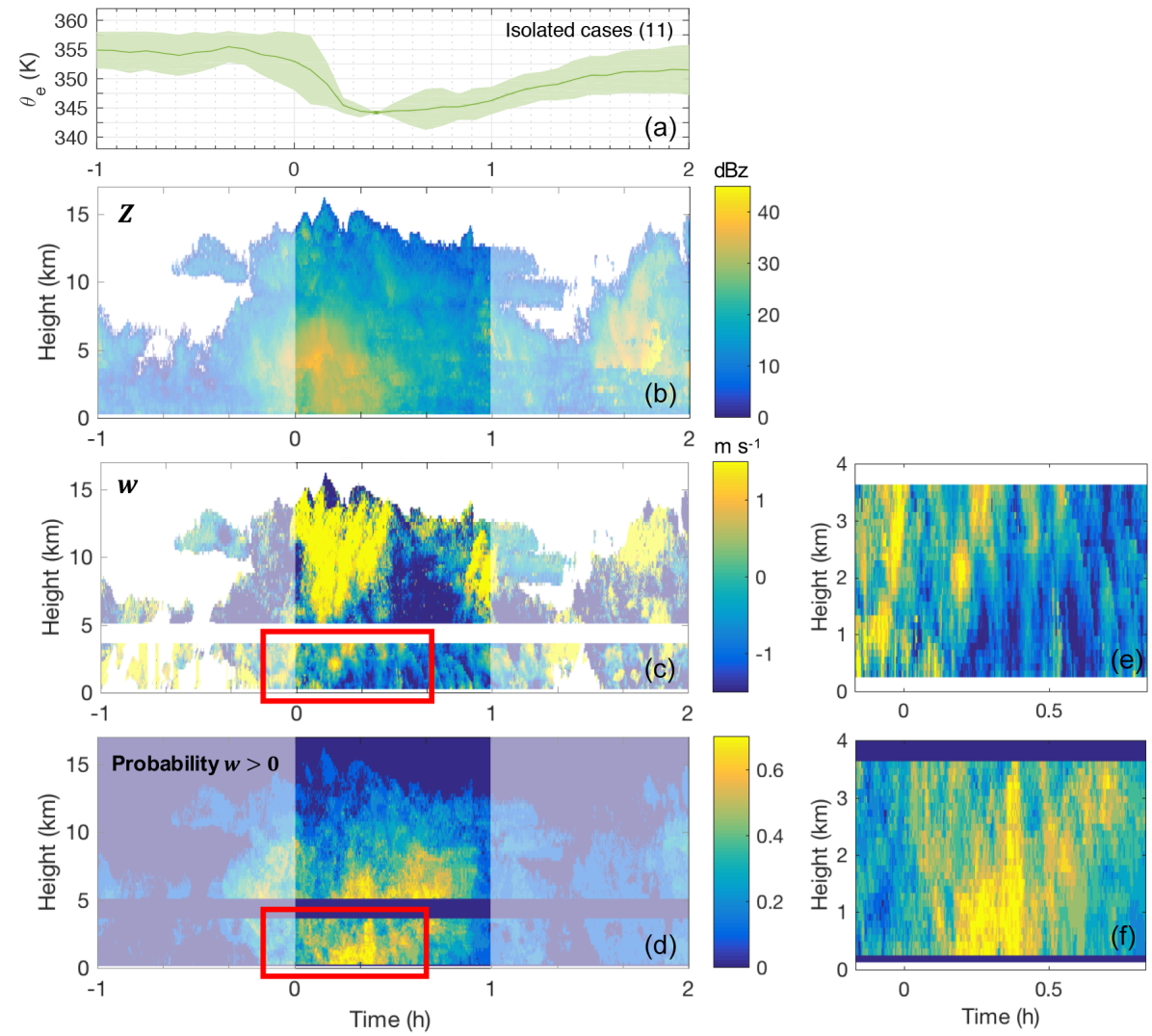

Figure 4. The composite $\theta_{\mathrm{e}}(\mathrm{K} ; \mathbf{a})$, mean reflectivity $(\mathrm{dBZ} ; \mathbf{b})$, mean vertical velocity $\left(\mathbf{c} ; \mathrm{m} \mathrm{s}^{-1}\right)$, and probability of $w<0 \mathrm{~m} \mathrm{~s}^{-1}$ (d) observed by the radar wind profiler at T3 leading and lagging the passage of isolated cells. Plots of $w(\mathbf{e})$ and probability(f) zoomed in time and height (as outlined in red) are shown to the right of the corresponding plots for visual clarity.

trievals, as there is large error associated with retrievals near the freezing level; Giangrande et al., 2016). It appears likely, however, that these downdrafts are discontinuous in height more often than not, as high probabilities are not observed coincidentally in the lowest levels beneath these downdrafts.
These middle- and upper-level downdrafts are documented in previous studies of MCSs, which suggest that they form in response to the pressure field (e.g., Biggerstaff and Houze, 1991), can occur quite close to the updraft (Lily, 1960; Fritsch, 1975), and are positively buoyant (Fovell and Ogura, 

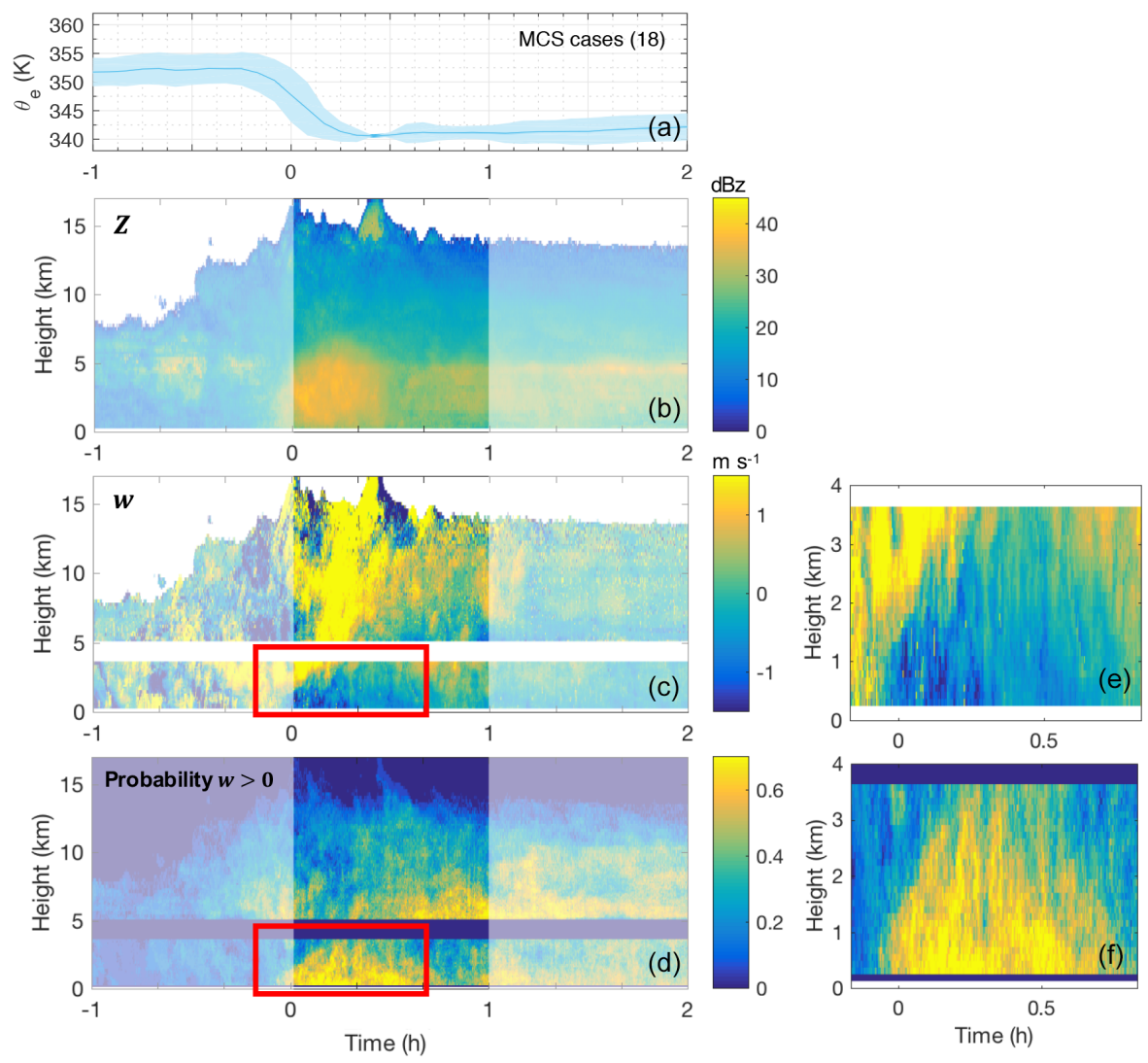

Figure 5. Same as Fig. 5, but leading and lagging the passage of MCSs.

1988; Jorgensen and LeMone, 1989; Sun et al., 1993). These motions produce gravity waves in the stratosphere, as is discussed in Fovell et al. (1992).

Figure 5 shows the same composites for the 18 MCSs observed. They, too, have high reflectivity (mean $>40 \mathrm{dBZ}$ ) in the 30 min coincident with the minimum $\theta_{\mathrm{e}}$ and a defined updraft extending up to the upper troposphere. Downdrafts occurring coincident with the minimum $\theta_{\mathrm{e}}$ are observed directly below the updraft signature in the mean vertical velocity panel, and the probabilities are greatest below the freezing level. There are likely also mesoscale downdrafts in the trailing stratiform region of the MCSs, although difficult to discern here, which Miller and Betts (1977) suggest are more dynamically driven than the precipitation-driven downdrafts associated with the leading-edge convection. These likely sustain the low $\theta_{\mathrm{e}}$ air in the boundary layer for hours after the initial drop, observed in Fig. 2. Vertical motions in the stratiform region are weaker than in the convective region, and on average, as in Cifelli and Rutledge (1994), rarely exceed $1 \mathrm{~m} \mathrm{~s}^{-1}$.

Figure 6 is a concise summary of the results presented in Figs. 4 and 5, showing the mean vertical velocity within the $30 \mathrm{~min}$ of sharpest $\Delta \theta_{\mathrm{e}}$ for MCSs and isolated cells. Means are for $w>0 \mathrm{~m} \mathrm{~s}^{-1}$ only (updrafts) or $w<0 \mathrm{~m} \mathrm{~s}^{-1}$ only (downdrafts) at each height (as in Giangrande et al.,
2016) and are thus characteristic of magnitudes rather than bulk air motions. Updraft and downdraft strength increases with height, consistent with results from previous studies evaluating a broader range of conditions (May and Rajopadhyaya, 1999; Kumar et al., 2015; Giangrande et al., 2016). The corresponding mean probability of observing such motions at each height is shown in the right panel. Probabilities, which can be interpreted loosely as convective area fractions (Kumar et al., 2015; Giangrande et al., 2016), are largest below the freezing level for downdrafts and in the 3-7 km region for updrafts. The probability of downdrafts for both isolated cells and MCSs increases nearly linearly towards the surface below the freezing level. Thus, this behavior in the lowest $3 \mathrm{~km}$ summarizes our results from the previous two figures and suggests that the mean properties of downdrafts are such that air accumulates along descent - analogous to mixing. The probability and vertical velocity for both MCSs and isolated cells correspond to mass flux profiles that increase nearly linearly throughout the lower troposphere for updrafts and that decrease nearly linearly throughout the lower troposphere for downdrafts, as seen in Giangrande et al. (2016) over a broader range of convective conditions. To give some sense of the error in these estimates, Wilson score intervals (lower bound/upper bound) for the $18 \mathrm{MCS}$ cases are roughly $0.16 / 0.23$ for a probability of $0.7,0.21 / 0.21$ 
for a probability of 0.5 , and $0.23 / 0.16$ for a probability of 0.3 ; for 11 events (as in the isolated cases), the intervals are roughly $0.19 / 0.28$ for a probability of $0.7,0.25 / 0.25$ for a probability of 0.5 , and $0.28 / 0.19$ for a probability of 0.3 .

These results, and those presented in the previous section, suggest a range of downdraft origin levels throughout the lowest few kilometers within both organized and unorganized convective systems. Several observational studies corroborate the evidence presented here that a majority of the air reaching the surface in deep convective downdrafts originates at low levels (Betts, 1976; Barnes and Garstang, 1982; Betts et al., 2002; de Szoke et al., 2017). Betts (1976) concluded that the downdraft air descends approximately only to the depth of the subcloud layer $(\sim 150 \mathrm{mbar})$. Betts et al. (2002) cited a range of $765-864 \mathrm{hPa}$ for the first levels at which the surface $\theta_{\mathrm{e}}$ values matched those of the air aloft. Additionally, there are many modeling studies that provide evidence of these low-level origins (Moncrieff and Miller, 1976; Torri and Kuang, 2016). Recently, Torri and Kuang (2016) used a Lagrangian particle dispersion model to show that precipitation-driven downdrafts originate at very low levels, citing an altitude of $1.5 \mathrm{~km}$ from the surface, with the mode of the distribution nearer to $1 \mathrm{~km}$. These conclusions are consistent with our results here, suggesting that downdraft parameterizations substantially weight the contribution of air from the lower troposphere (e.g., with substantial mixing and/or modifying the height of downdraft origin).

\section{Relating cold pool thermodynamics to precipitation}

As seen in previous sections, the passage of both organized and unorganized convection can lead to substantial decreases in $\theta_{\mathrm{e}}$ resulting mainly from precipitation-driven downdrafts formed from the leading convective cells. In this section, we search for robust statistical relationships between key thermodynamic variables for potential use in improving downdraft parameterizations in GCMs. These statistics differ from those presented in Figs. 2-6, as these statistics are not conditioned on convection type and they sample both precipitating and non-precipitating points within the time series analyzed. All data available at the surface meteorological station during the GoAmazon2014/5 campaign from 10 January 2014 to 20 October 2015 are included in these statistics.

The first of these statistics conditionally averages precipitation rate by $\Delta \theta_{\mathrm{e}}$ (Fig. 7), variants of which have been discussed in previous studies (Barnes and Garstang, 1982; Wang et al., 2016). Our statistics mimic those shown in previous work relating column-integrated moisture to deep convection over tropical land (Schiro et al., 2016) and ocean (Neelin et al., 2009; Holloway and Neelin, 2009). The direction of causality in the CWV-precipitation statistics, however, is the opposite of what is presented here. CWV is thought to primarily be the cause of intense precipitation and deep convection, while here the $\Delta \theta_{\mathrm{e}}$ observed is a direct result of the precipitation processes and associated downdraft. Nevertheless, examining the distribution of $\Delta \theta_{\mathrm{e}}$ observed at the surface and magnitudes of the rain rates associated with the largest drops in $\Delta \theta_{\mathrm{e}}$ across different regions in the tropics can place bounds on downdraft behavior. We will also conditionally average $\Delta \theta_{\mathrm{e}}$ by precipitation rate, a more physically consistent direction of causality.

Figure 7 shows precipitation rates binned by $\Delta \theta_{\mathrm{e}}$ for in situ and radar-derived precipitation. Bins are $1 \mathrm{~K}$ in width (bins with less than five observations are eliminated from the analysis) and precipitating events are defined as having rain rates greater than $2 \mathrm{~mm} \mathrm{~h}^{-1}$. This threshold is chosen based on results from Barnes and Garstang (1982), who suggested it as a minimum precipitation rate for observing coincident decreases in $\theta_{\mathrm{e}}$ at the surface. These statistics mainly suggest that a majority of the substantial decreases in $\theta_{\mathrm{e}}$ at the surface occur coincidently with heavy precipitation, which is particularly evident from the sharp increase in probability of precipitation (middle panel).

$S$-band radar data are averaged in 25 and $100 \mathrm{~km}$ grid boxes surrounding the GoAmazon2014/5 site to examine the precipitation $-\Delta \theta_{\mathrm{e}}$ relation with model diagnostics in mind (Fig. 7). The $\Delta \theta_{\mathrm{e}}$ shown is in situ, since we do not have spatial information in the moisture and temperature fields at a high enough temporal frequency to match the radar data. Out to $25 \mathrm{~km}$, the statistics are very similar to those observed using in situ precipitation. Theoretical (Romps and Jevanjee, 2016), modeling (Tompkins, 2001; Feng et al., 2015), and observational (Feng et al., 2015) studies have all examined typical sizes of cold pools, which can be on the order of $25 \mathrm{~km}$ in diameter for any one cell. Cold pools can combine, however, to form a larger, coherent mesoscale-sized cold pool (radius of $50 \mathrm{~km}$ or greater), as is commonly associated with mesoscale convective systems (Fujita, 1959; Johnson and Hamilton, 1988). Therefore, it is likely that our use of the in situ $\Delta \theta_{\mathrm{e}}$, assuming cold pool properties are somewhat homogeneous in space, is appropriate for scales up to $25 \mathrm{~km}$. Beyond this scale, it is likely that the $\Delta \theta_{\mathrm{e}}$ would be smoothed by averaging, particularly for the smaller isolated cells, as would precipitation. For the conditional average precipitation (Fig. 7), this effect may be seen at the $100 \mathrm{~km}$ averaging scale. The probabilities are, however, robust to averaging. This suggests that when drops in $\theta_{\mathrm{e}}$ occur locally, there tends to be good correspondence to precipitation both locally and in the surrounding 25 and $100 \mathrm{~km}$ averaging areas.

The width of the distribution of precipitating points is of greatest interest here. The distribution of precipitating points peaks just shy of a $\Delta \theta_{\mathrm{e}}$ of $0 \mathrm{~K}$, indicating that most precipitation events have low rain rates and do not occur coincidently with an appreciable drop in $\theta_{\mathrm{e}}$. The frequency of precipitation drops off roughly exponentially towards lower $\Delta \theta_{\mathrm{e}}$. An interesting feature is the lower bound observed in $\Delta \theta_{\mathrm{e}}$ near $-15 \mathrm{~K}$. The mean profiles in Fig. 3 show that, on average, this value of $-15 \mathrm{~K}$ would be consistent with air originating from the level of minimum $\theta_{\mathrm{e}}$ and descending undiluted to 

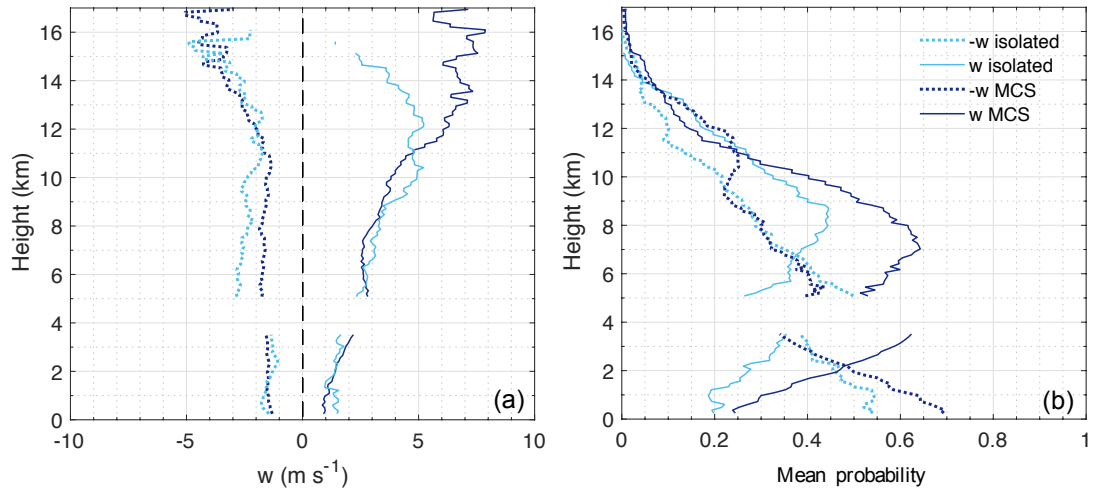

Figure 6. (a) Mean vertical velocity profiles for MCSs and isolated cells for downdrafts $\left(w<0 \mathrm{~m} \mathrm{~s}^{-1}\right.$; dashed) and updrafts $\left(w>0 \mathrm{~m} \mathrm{~s}{ }^{-1}\right.$; solid). (b) Mean probability of observing updrafts or downdrafts as a function of altitude. Means are composited from data within 30 min of largest drop in $\Delta \theta_{\mathrm{e}}(0-0.5 \mathrm{~h}$ in Figs. 4 and 5).
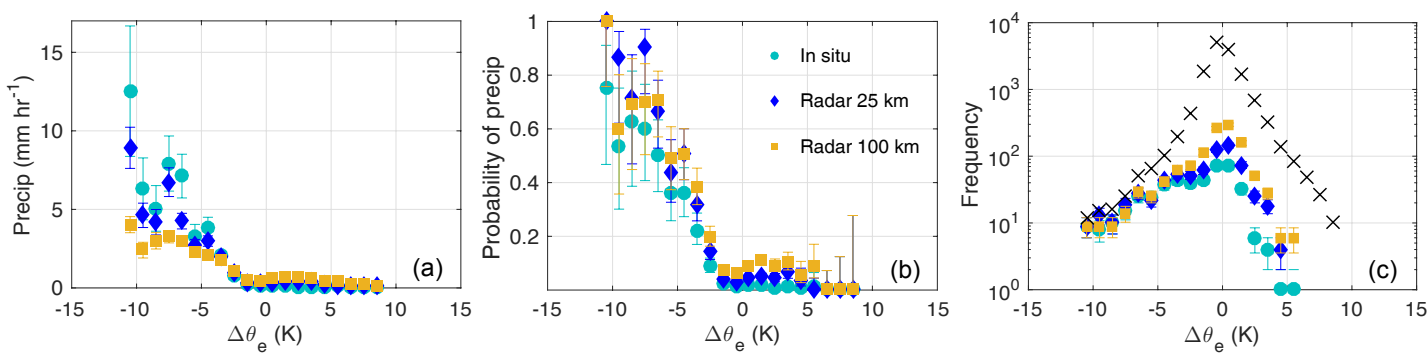

Figure 7. (a) Precipitation ( $1 \mathrm{~h}$ averages) conditionally averaged by coincident changes in equivalent potential temperature $\left(\Delta \theta_{\mathrm{e}}\right)$ at the GoAmazon site. Precipitation values corresponds to the $\theta_{\mathrm{e}}$ values at the end of each differencing interval. Bins are a width of $1^{\circ}$ and error bars represent the standard error. (b) The probability of precipitation $\left(>2 \mathrm{~mm} \mathrm{~h}^{-1}\right)$ occurring for a given $\Delta \theta_{\mathrm{e}}$. Error bars represent Wilson score intervals from 5 to $95 \%$. (c) The frequency of occurrence of $\Delta \theta_{\mathrm{e}}$ and precipitation for a given $\Delta \theta_{\mathrm{e}}$ (precipitation $>2 \mathrm{~mm} \mathrm{~h}^{-1}$ ). Precipitation derived from $S$-band radar reflectivity at spatial averages over 25 and $100 \mathrm{~km}$ grid boxes surrounding the GoAmazon site is included for comparison to the in situ precipitation.

the surface. The frequency of observing these values suggests that air very rarely reaches the surface from these altitudes ( $3 \mathrm{~km}$ or higher) undiluted. The $\theta_{\mathrm{e}}$ probability distribution is consistent with the results of Sect. 5, indicating that the probability of air from a given level of origin reaching the surface increases toward the surface through the lowest $3 \mathrm{~km}$.

Figure 8 shows remarkable similarity in these statistics when comparing across regions to a DOE ARM site at Manus Island in the tropical western Pacific. As $\Delta \theta_{\mathrm{e}}$ decreases, in situ precipitation rates sharply increase. The probability density functions (PDFs), as well as the steepness and locations of the pickups, are remarkably consistent. Again, the sharpness of these curves is a result of the strongest precipitation events coinciding with the strongest decreases in $\theta_{\mathrm{e}}$, shown in the middle panels in Fig. 8, where the probability of observing coincident precipitation is greatest at low $\Delta \theta_{\mathrm{e}}$.

It is then of interest to see if for a given precipitation rate we can expect a particular $\Delta \theta_{\mathrm{e}}$, as this is the proper direction of causality. Figure 9 conditionally averages $\Delta \theta_{\mathrm{e}}$ by precipitation rate ( $1 \mathrm{~h}$ averages). The minimum $\Delta \theta_{\mathrm{e}}$ and maximum precipitation within a $3 \mathrm{~h}$ window are averaged to minimize the effects of local precipitation maxima occurring slightly before or after the maximum in $\Delta \theta_{\mathrm{e}}$. Comparing Fig. 8 and Fig. 9 shows that there can be strong precipitation events without large, corresponding decreases in surface $\theta_{\mathrm{e}}$, but that large decreases in surface $\theta_{\mathrm{e}}$ are almost always associated with heavy precipitation. Beyond about $10 \mathrm{~mm} \mathrm{~h}^{-1}$ there is a high probability of observing large, negative $\Delta \theta_{\mathrm{e}}$ and an apparent limit in mean $\theta_{\mathrm{e}}$ decreases with rain rate. This makes physical sense, as discussed above (see also Barnes and Garstang, 1982), since cooling is limited by the maximum difference between the surface $\theta_{\mathrm{e}}$ and the $\theta_{\mathrm{e}}$ minimum aloft.

The average $\Delta \theta_{\mathrm{e}}$ for rain rates exceeding $10 \mathrm{~mm} \mathrm{~h}^{-1}$ is about $-5 \mathrm{~K}$ for the Amazon and $-4 \mathrm{~K}$ for Manus Island (Fig. 9). This statistic could be of use in constraining downdraft parameters to be consistent with surface cooling and drying observed in nature. The results for $100 \mathrm{~km}$ overlaid in Fig. 9 suggest that even though precipitation rates at $100 \mathrm{~km}$ are not simply proportional to in situ rain rates, the main feature of the statistic is robust to averaging precipitation out to a typical GCM grid scale. There are still, however, open 

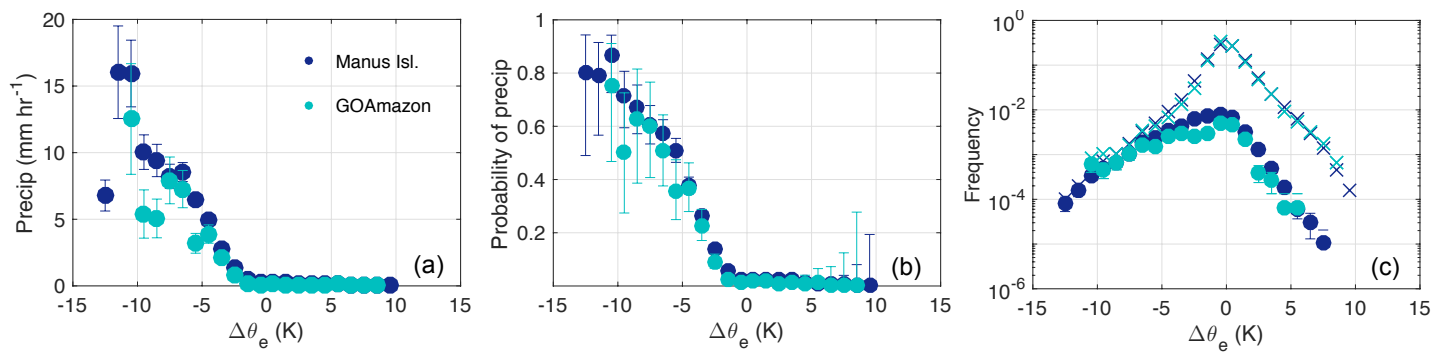

Figure 8. Same as Fig. 7, except comparing results from in situ data only at the GoAmazon2014/5 site (aqua) and the DOE ARM site at Manus Island (navy blue).
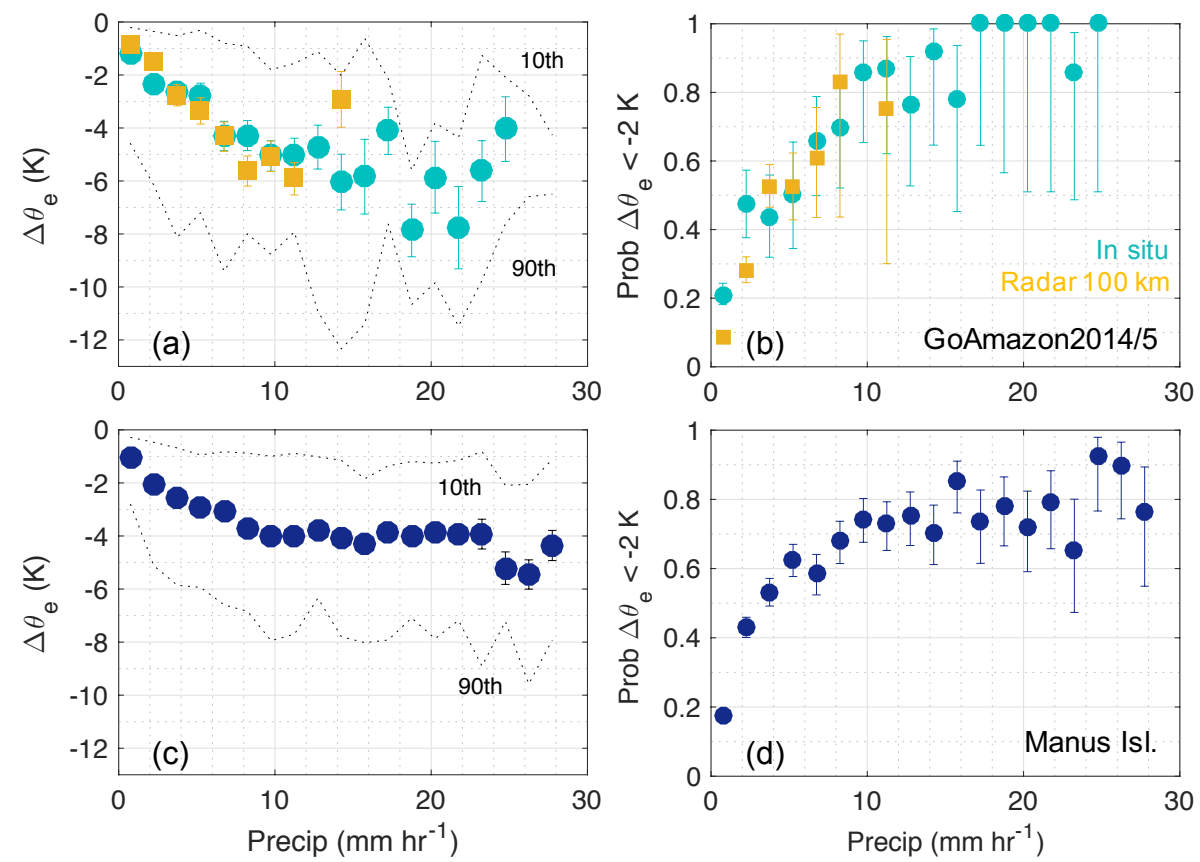

Figure 9. $\Delta \theta_{\mathrm{e}}$ conditionally averaged by coincident precipitation ( $1 \mathrm{~h}$ averages) at the GoAmazon site (a, b) and at Manus Island (c, d). Precipitation values corresponds to the $\theta_{\mathrm{e}}$ values at the end of each differencing interval. Bins are a width of $1.5 \mathrm{~mm} \mathrm{hr}^{-1}$. Error bars represent the standard error $(\mathbf{a}, \mathbf{c})$, and the 10th and 90th percentile values for each bin are drawn for reference (b, d). Error bars on the probability represent Wilson score intervals from 5 to $95 \%$.

questions about scale dependence and how much cooling or drying should be observed for varying space and timescales, given that we are using in situ $\Delta \theta_{\mathrm{e}}$ for all of the statistics presented. Overall, if convective precipitation is present in a GCM grid, a corresponding $\Delta \theta_{\mathrm{e}}$ should result within a range consistent to those observed here, subject to scale dependence.

To summarize the results from Figs. 7-9 and provide additional diagnostics, we can ask what fraction of precipitation occurs within a given time window of an appreciable drop in $\theta_{\mathrm{e}}$, and how this fraction changes with precipitation intensity. At the GoAmazon $2014 / 5$ site, for $\Delta \theta_{\mathrm{e}} \leq-2 \mathrm{~K}$, the fraction of precipitation events within the same hour exceeding 1 , 5 , and $10 \mathrm{~mm} \mathrm{~h}^{-1}$, respectively, is 43,63 , and $74 \%$. Similar fractions (though smaller) are found at Manus Island: 37, 53, and $63 \%$, respectively. Increasing the required value of $\Delta \theta_{\mathrm{e}}$ yields smaller fractions; e.g., for $\Delta \theta_{\mathrm{e}} \leq-4 \mathrm{~K}$, corresponding fractions at the GoAmazon2014/5 site are about $75 \%$ of the above values (37, 53, and $62 \%$, respectively). Based on arguments presented above about typical cold pool sizes, these result are likely applicable to GCM grid scales of $0.25^{\circ}$ or less, with evidence of consistency out to $1^{\circ}$. 


\section{Conclusions}

Convective events sampled during the GoAmazon2014/5 campaign compare downdraft characteristics between MCSs and isolated cells and examine their respective effects on surface thermodynamics. All events included in the analysis passed directly over the GoAmazon2014/5 site with minimum precipitation rates of $10 \mathrm{~mm} \mathrm{~h}^{-1}$ and $\Delta \theta_{\mathrm{e}}$ less than or equal to $-5 \mathrm{~K}$. The isolated events sampled occurred in the afternoon hours only and were characterized by average decreases of $1.5 \mathrm{~g} \mathrm{~kg}^{-1}$ in specific humidity, $4.2 \mathrm{~K}$ in temperature, and $9.6 \mathrm{~K}$ in $\theta_{\mathrm{e}}$, with an increase of $4.2 \mathrm{~m} \mathrm{~s}^{-1}$ in wind speed at the surface. More than half (59\%) of the deficit in $\theta_{\mathrm{e}}$ observed with the passage of the cells recovers within $1 \mathrm{~h}$, on average, with the moisture recovering faster than temperature and constituting a larger fraction of the total $\theta_{\mathrm{e}}$ recovered. MCSs show similar decreases in temperature $(4.2 \mathrm{~K})$, moisture $\left(1.6 \mathrm{~g} \mathrm{~kg}^{-1}\right)$, and thus $\theta_{\mathrm{e}}(9.7 \mathrm{~K})$ at the surface. The $\theta_{\mathrm{e}}$ recovers more slowly for MCSs due to the mesoscale downdrafts and associated precipitation in their trailing stratiform regions.

Vertical velocity profiles from a radar wind profiler show that the probability of observing downdraft air during the 30 min of observed minimum $\Delta \theta_{\mathrm{e}}$ increases with decreasing height in the lowest $3 \mathrm{~km}$ for both isolated cells and MCSs. This vertical structure of the downdraft probability is consistent with negative vertical velocities originating at various levels within this layer and continuing to the surface. Considering complementary thermodynamic arguments, without mixing, profiles of $\theta_{\mathrm{e}}$ suggest that origin levels at average altitudes of 1.4 and $2.1 \mathrm{~km}$ for isolated cells and MCSs, respectively, would be consistent with average cold pool $\theta_{\mathrm{e}}$ for these cases. A minimum in $\theta_{\mathrm{e}}$ is observed between 3 and $7 \mathrm{~km}$, on average, so for air to originate above $3 \mathrm{~km}$, simple plume calculations suggest that downdrafts in MCSs would have to be mixing with environmental air at an approximate rate of $0.002 \mathrm{hPa}^{-1}$ along descent and at a rate roughly 2 times greater $\left(0.004 \mathrm{hPa}^{-1}\right)$ for isolated cells. This would imply mass entering the downdraft throughout the lowest few kilometers. Overall, the vertical velocity and thermodynamic constraints are consistent in suggesting a spectrum of downdraft mass origin levels throughout the lowest few kilometers.

Robust statistical relationships between $\Delta \theta_{\mathrm{e}}$ and precipitation are examined from nearly 2 years of data at the GoAmazon2014/5 site and 15 years of data at the DOE ARM site at Manus Island in the tropical western Pacific. We conditionally average precipitation by $\Delta \theta_{\mathrm{e}}$, similar to the statistics of precipitation conditioned on a thermodynamic quantity we consider for convective onset statistics. Here, however, the most likely direction of causality differs in that the $\theta_{\mathrm{e}}$ drop is caused by the downdraft that delivers the precipitation (as opposed to the thermodynamic profile providing convective available potential energy for an updraft). For in situ precipitation, the conditional average precipitation ex- hibits a sharp increase with decreasing $\Delta \theta_{\mathrm{e}}$, which is similar in magnitude over land and ocean, reaching roughly $10 \mathrm{~mm} \mathrm{~h}^{-1}$ at a $\Delta \theta_{\mathrm{e}}$ of $-10 \mathrm{~K}$. For area-averaged precipitation on scales typical of GCM grids, precipitation magnitudes are smaller for strong, negative $\Delta \theta_{\mathrm{e}}$, consistent with events with large $\Delta \theta_{\mathrm{e}}$ occurring at localized downdraft locations within a larger system with smaller area-average precipitation. The probability distributions of $\Delta \theta_{\mathrm{e}}$ (for precipitating and non-precipitating points) over land and ocean are also remarkably similar. Distributions show exponentially decreasing probability with decreasing $\Delta \theta_{\mathrm{e}}$, providing additional evidence that downdraft plumes originating in the lowest levels are orders of magnitude more likely than plumes descending with little mixing from the height of minimum $\theta_{\mathrm{e}}$. Conditionally averaging $\Delta \theta_{\mathrm{e}}$ by precipitation (the most likely direction of causality) suggests an average limit in $\Delta \theta_{\mathrm{e}}$ of -4 to $-5 \mathrm{~K}$ given high precipitation typical of downdraft conditions. The corresponding 90th percentile yields $\Delta \theta_{\mathrm{e}}$ of roughly $-10 \mathrm{~K}$, consistent with results obtained from composting strong downdrafts. The robustness of these statistics over land and ocean, and to averaging in space at scales appropriate to a typical GCM resolution, suggests possible use of these statistics as model diagnostic tools and observational constraints for downdraft parameterizations.

Data availability. All data used in this study can be accessed through the Department of Energy Atmospheric Radiation Measurement Data Archive (www.arm.gov); please see references for DOIs, datasets, and date ranges used. Analysis scripts and processed data are available upon request. Please contact the corresponding author atkschiro@atmos.ucla.edu. Vertical velocity retrievals from radar wind profiler data are also available upon request; please contact Scott Giangrande at sgrande@bnl.gov.

\section{The Supplement related to this article is available online at https://doi.org/10.5194/acp-18-1997-2018-supplement.}

Competing interests. The authors declare that they have no conflict of interest.

Special issue statement. This article is part of the special issue "Observations and Modeling of the Green Ocean Amazon (GoAmazon2014/5) (ACP/AMT/GI/GMD inter-journal SI)". It is not associated with a conference.

Acknowledgements. The U.S. Department of Energy Atmospheric Radiation Measurement (ARM) Climate Research Facility GoAmazon2014/5 and Tropical West Pacific field campaign data were essential to this work. This research was supported in part by the Office of Biological and Environmental Research of 
the U.S. Department of Energy grant DE-SC0011074, National Science Foundation grant AGS-1505198, National Oceanic and Atmospheric Administration grant NA14OAR4310274, and a Dissertation Year from the University of California, Los Angeles Fellowship (KS). Parts of this material have been presented at the Fall 2016 meeting of the American Geophysical Union and have formed part of Kathleen Schiro's PhD thesis. We thank Scott Giangrande for providing RWP-derived vertical velocity and for helpful discussions.

Edited by: Paul Zieger

Reviewed by: three anonymous referees

\section{References}

Atmospheric Radiation Measurement (ARM) Climate Research Facility: updated hourly, Meteorological Measurements associated with the Aerosol Observing System (AOSMET), 2014-01-10 to 2015-10-20, ARM Mobile Facility (MAO) Manacapuru, Amazonas, Brazil; MAOS (S1), compiled by: Koontz, A., Kyrouac, J., and Springston, S., Atmospheric Radiation Measurement (ARM) Climate Research Facility Data Archive: Oak Ridge, Tennessee, USA, https://doi.org/10.5439/1025153, 2013a.

Atmospheric Radiation Measurement (ARM) Climate Research Facility: updated hourly, Balloon-Borne Sounding System (SONDEWNPN), 2014-01-10 to 2015-10-20, ARM Mobile Facility (MAO) Manacapuru, Amazonas, Brazil; AMF1 (M1), compiled by: Holdridge, D., Kyrouac, J., and Coulter, R., Atmospheric Radiation Measurement (ARM) Climate Research Facility Data Archive: Oak Ridge, Tennessee, USA, https://doi.org/10.5439/1021460, 2013b.

Atmospheric Radiation Measurement (ARM) Climate Research Facility: updated hourly, Eddy Correlation Flux Measurement System (30ECOR), 2014-04-03 to 2015-10-20, ARM Mobile Facility (MAO) Manacapuru, Amazonas, Brazil; AMF1 (M1), compiled by: Cook, D., Atmospheric Radiation Measurement (ARM) Climate Research Facility Data Archive: Oak Ridge, Tennessee, USA, https://doi.org/10.5439/1025039, 2014.

Atmospheric Radiation Measurement (ARM) Climate Research Campaign Data: Observations and Modeling of the Green Ocean Amazon (GOAMAZON), SIPAM Manaus S-Band Radar, 10 January 2014-20 October 2015, 36 $3.1489^{\circ} \mathrm{S}, 59.9914^{\circ} \mathrm{W}$, Manaus, Amazonas, Brazil (T1), processed by: Schumacher, C., www.arm.gov (last access: 8 February 2018), 2015.

Atmospheric Radiation Measurement (ARM) Climate Research Facility Observations and Modeling of the Green Ocean Amazon (GOAMAZON): Radar Wind Profiler (1290RWPPRECIPMOM), Atmospheric Radiation Measurement (ARM) Climate Research Facility Data Archive: Oak Ridge, Tenn. https://doi.org/10.5439/1256461, 2015.

Barnes, G. M. and Garstang, M.: Subcloud Layer Energetics of Precipitating Convection, Mon. Weather Rev., 110, 102-117, 1982.

Betts, A.: Non-precipitating cumulus convection and its parameterization, Q. J. Roy. Meteor. Soc., 99, 178-196, 1973.

Betts, A. K.: The thermodynamic transformation of the tropical subcloud layer by precipitation and downdrafts, J. Atmos. Sci., 33, 1008-1020, 1976.
Betts, A. K. and Jakob, C.: Study of diurnal cycle of convective precipitation over Amazonia using a single column model, J. Geophys. Res., 107, 4732, https://doi.org/10.1029/2002JD002264, 2002.

Betts, A. K. and Silva Dias, M. F.: Unsaturated downdraft thermodynamics in cumulonimbus, J. Atmos. Sci., 36, 1061-1071, 1979.

Biggerstaff, M. I. and Houze Jr., R. A.: Kinematic and precipitation structure of the 10-11 June 1985 squall line, Mon. Weather Rev., 119, 3034-3065, 1991.

Boing, S. J., Jonker, H J. J., Siebesma, A. P., and Grabowski, W. W.: Influence of the Subcloud Layer on the Development of a Deep Convective Ensemble, J. Atmos. Sci., 69, 2682-2698, 2012.

Bolton, D.: The computation of equivalent potential temperature, Mon. Weather Rev., 108, 1046-1053, 1980.

Brown, R. G. and Zhang, C.: Variability of midtropospheric moisture and its effect on cloud-top height distribution during TOGA COARE, J. Atmos. Sci., 54, 2760-2774, 1997.

Byers, H. R. and Braham, R. R.: The thunderstorm: report of the Thunderstorm Project, US Government Printing Office, 1949.

Charba, J.: Application of a gravity wave current model to analysis of a squall-line gust front, Mon. Weather Rev., 102, 140-156, 1974.

Cifelli, R. and Rutledge, S. A.: Vertical motion structure in maritime continent mesoscale convective systems: Results from a 50-MHz profiler, J. Atmos. Sci., 51, 2631-2652, 1994.

Del Genio, A. D., Chen, Y., Kim, D., and Yao, M.-S.: The MJO Transition from Shallow to Deep Convection in CloudSat/CALIPSO Data and GISS GCM Simulations, J. Climate, 25, 3755-3770, 2012.

de Szoeke, S. P., Skyllingstad, E. D., Zuidema, P., and Chandra, A. S.: Cold pools and their influence on the tropical marine boundary layer, J. Atmos. Sci., 74, 1149-1168, https://doi.org/10.1175/JAS-D-16-0264.1, 2017.

Emanuel, K. A.: Atmospheric Convection, 1st Edn., Oxford University Press, 580 pp., 1994

Engerer, N. A., Stensrud, D. J., and Coniglio, M. C.: Surface characteristics of observed cold pools, Mon. Weather Rev., 136, 48394849, 2008.

Feng, Z., Hagos, S., Rowe, A. K., Burleyson, C. D., Martini, M. N., and Szoeke, S. P.: Mechanisms of convective cloud organization by cold pools over tropical warm ocean during the AMIE/DYNAMO field campaign, J. Adv. Model. Earth Sy., 7, 357-381, 2015.

Fritsch, J. M.: Cumulus dynamics: Local compensating subsidence and its implications for cumulus parameterization, Pure Appl. Geophys., 113, 851-867, 1975.

Fovell, R., Durran, D., and Holton, J. R.: Numerical simulations of convectively generated stratospheric gravity waves, J. Atmos. Sci., 49, 1427-1442, 1992.

Fovell, R. G. and Ogura, Y.: Numerical simulation of a midlatitude squall line in two dimensions, J. Atmos. Sci., 45, 3846-3879, 1988.

Fovell, R. G. and Tan, P. H.: The temporal behavior of numerically simulated multicell-type storms. Part II: The convective cell life cycle and cell regeneration, Mon. Weather Rev., 126, 551-577, 1998.

Fujita, T.: Precipitation and cold air production in mesoscale thunderstorm systems, J. Meteorol., 16, 454-466, 1959. 
Gerken, T., Wei, D., Chase, R. J., Fuentes, J. D., Schumacher, C., Machado, L., Andreoli, R. V., Chamecki, M., Ferreira de Souza, R. A., Freire, L. S., Jardine, A. B., Manzi, A. O., Nascimento dos Santos, R. M., Randow, C., Santos Costa, P., Stoy, P. C., Tóta, J., and Trowbridge, A. M.: Downward transport of ozone rich air and implications for atmospheric chemistry in the Amazon rainforest, Atmos. Environ., 124, 64-76, 2016.

Giangrande, S. E., Toto, T., Jensen, M. P., Bartholomew, M. J., Feng, Z., Protat, A., Williams, C. R., Schumacher, C., and Machado, L.: Convective cloud vertical velocity and mass-flux characteristics from radar wind profiler observations during GoAmazon2014/5, J. Geophys. Res.-Atmos., 121, https://doi.org/10.1002/2016JD025303, 2016.

Goff, R.: Vertical structure of thunderstorm outflows, Mon. Weather Rev., 104, 1429-1440, 1976.

Hohenegger, C. and Bretherton, C. S.: Simulating deep convection with a shallow convection scheme, Atmos. Chem. Phys., 11, 10389-10406, https://doi.org/10.5194/acp-11-10389-2011, 2011.

Holloway, C. E. and Neelin, J. D.: Moisture Vertical Structure, Column Water Vapor, and Tropical Deep Convection, J. Atmos. Sci., 66, 1665-1683, 2009.

Houze, R. A.: Cloud Dynamics, Academic, San Diego, Calif, 573 pp., 1993.

Houze, R. A.: Mesoscale convective systems, Rev. Geophys., 42, https://doi.org/10.1029/2004RG000150, 2004.

Houze, R. A., Smull, B. F., and Dodge, P.: Mesoscale organization of springtime rainstorms in Oklahoma, Mon. Weather Rev., 118, 613-654, 1990.

Johnson, R. H. and Hamilton, P. J.: The relationship of surface pressure features to the precipitation and airflow structure of an intense midlatitude squall line, Mon. Weather Rev., 116, 14441473,1988

Jorgensen, D. P. and LeMone, M. A.: Vertical velocity characteristics of oceanic convection, J. Atmos. Sci., 46, 621-640, 1989.

Kain, J. S. and Fritsch, J. M.: A one-dimensional entraining/detraining plume model and its application in convective parameterization, J. Atmos. Sci., 47, 2784-2802, 1990.

Kamburova, P. L. and Ludlam, F. H.: Rainfall evaporation in thunderstorm downdraughts, Q. J. Roy. Meteor. Soc., 92, 510-518, 1966.

Khairoutdinov, M. and Randall, D.: High-resolution simulation of shallow-to-deep convection transition over land, J. Atmos. Sci., 63, 3421-3436, 2006.

Khairoutdinov, M. F., Krueger, S. K., Moeng, C. H., Bogenschutz, P. A., and Randall, D. A.: Large-eddy simulation of maritime deep tropical convection, J. Adv. Model. Earth Sy., 1, https://doi.org/10.3894/JAMES.2009.1.15, 2009.

Kim, D., Del Genio, A. D., and Yao, M.-S.: Moist convection scheme in Model E2. NOAA Tech. Note, 9 pp., available at: http://www.giss.nasa.gov/tools/modelE/docs/kim_ moistconvection.pdf (last access: 8 February 2018), 2011.

Knupp, K. R. and Cotton, W. R.: Convective cloud downdraft structure: An interpretive survey, Rev. Geophys., 23, 183-215, 1985.

Kumar, V. V., Jakob, C., Protat, A., Williams, C. R., and May, P. T.: Mass-flux characteristics of tropical cumulus clouds from wind profiler observations at Darwin, Australia, J. Atmos. Sci., 72, 1837-1855, 2015.
Langenbrunner, B. and Neelin, J. D.: Multiobjective constraints for climate model parameter choices: Pragmatic Pareto fronts in CESM1, J. Adv. Model. Earth Sy., 9, 2008-2026, https://doi.org/10.1002/2017MS000942, 2018.

Li, Z., Zuidema, P., and Zhu, P.: Simulated convective invigoration processes at trade wind cumulus cold pool boundaries, J. Atmos. Sci., 71, 2823-2841, 2014

Lily, D.: On the theory of disturbances in a conditionally unstable atmosphere, Mon. Weather Rev., 88, 1-17, 1960.

Lima, M. A. and Wilson, J. W.: Convective storm initiation in a moist tropical environment, Mon. Weather Rev., 136, 18471864, 2008.

Martin, S. T., Artaxo, P., Machado, L. A. T., Manzi, A. O., Souza, R. A. F., Schumacher, C., Wang, J., Andreae, M. O., Barbosa, H. M. J., Fan, J., Fisch, G., Goldstein, A. H., Guenther, A., Jimenez, J. L., Pöschl, U., Silva Dias, M. A., Smith, J. N., and Wendisch, M.: Introduction: Observations and Modeling of the Green Ocean Amazon (GoAmazon2014/5), Atmos. Chem. Phys., 16, 47854797, https://doi.org/10.5194/acp-16-4785-2016, 2016.

Maloney, E. D. and Hartmann, D. L.: The sensitivity of intraseasonal variability in the NCAR CCM3 to changes in convective parameterization, J. Climate, 14, 2015-2034, 2001.

May, P. T. and Rajopadhyaya, D. K.: Vertical Velocity Characteristics of Deep Convection over Darwin, Australia, Mon. Weather Rev., 127, 1056-1071, 1998.

Miller, M. J. and Betts, A. K.: Traveling convective storms over Venezuela, Mon. Weather Rev., 105, 833-848, 1977.

Moncrieff, M. W. and Miller, M. J.: The dynamics and simulation of tropical cumulonimbus and squall lines, Q. J. Roy. Meteor. Soc., 102, 373-394, 1976.

Neelin, J. D., Peters, O., and Hales, K.: The Transition to Strong Convection, J. Atmos. Sci., 66, 2367-2384, 2009.

Pritchard, M. S., Moncrieff, M. W., and Somerville, R. C.: Orogenic propagating precipitation systems over the United States in a global climate model with embedded explicit convection, J. Atmos. Sci., 68, 1821-1840, 2011.

Purdom, J. F.: Some uses of high-resolution GOES imagery in the mesoscale forecasting of convection and its behavior, Mon. Weather Rev., 104, 1474-1483, 1976.

Rotunno, R., Klemp, J. B., and Weisman, M. L.: A Theory for Strong, Long-Lived Squall Lines, J. Atmos. Sci., 45, 463-485, 1988.

Rio, C., Hourdin, F., Grandpeix, J. Y., and Lafore, J. P.: Shifting the diurnal cycle of parameterized deep convection over land, Geophys. Res. Lett., 36, https://doi.org/10.1029/2008GL036779, 2009.

Romps, D. M. and Jeevanjee, N.: On the sizes and lifetimes of cold pools, Q. J. Roy. Meteor. Soc., 142, 1517-1527, 2016.

Rowe, A. K. and Houze Jr., R. A.: Cloud organization and growth during the transition from suppressed to active MJO conditions, J. Geophys. Res.-Atmos., 120, 10324-10350, 2015.

Sahany, S. and Nanjundiah, R. S.: Impact of convective downdrafts on model simulations: results from aqua-planet integrations, Ann. Geophys., 26, 1877-1887, 2008.

Sahany, S., Neelin, J. D., Hales, K., and Neale, R. B.: Temperaturemoisture dependence of the deep convective transition as a constraint on entrainment in climate models, J. Atmos. Sci., 69, 1340-1358, 2012. 
Schiro, K. A., Neelin, J. D., Adams, D. K., and Lintner, B. R.: Deep Convection and Column Water Vapor over Tropical Land versus Tropical Ocean: A Comparison between the Amazon and the Tropical Western Pacific, J. Atmos. Sci., 73, 4043-4063, 2016.

Schlemmer, L. and Hohenegger, C.: The Formation of Wider and Deeper Clouds as a Result of Cold-Pool Dynamics, J. Atmos. Sci., 71, 2842-2858, 2014.

Srivastava, R. C.: A model of intense downdrafts driven by the melting and evaporation of precipitation, J. Atmos. Sci., 44, 17521774, 1987.

Sun, J., Braun, S., Biggerstaff, M. I., Fovell, R. G., and Houze Jr., R. A.: Warm upper-level downdrafts associated with a squall line, Mon. Weather Rev., 121, 2919-2927, 1993.

Taylor, C. M., Belusic, D., Guichard, F., Parker, D. J., Vischel, T., Bock, O., Harris, P. P., Janicot, S., Klein, C., and Panthou, G.: Frequency of extreme Sahelian storms tripled since 1982 in satellite observations, Nature, 544, 475-478, 2017.

Terai, C. R. and Wood, R.: Aircraft observations of cold pools under marine stratocumulus, Atmos. Chem. Phys., 13, 9899-9914, https://doi.org/10.5194/acp-13-9899-2013, 2013.

Tiedtke, M.: A comprehensive mass flux scheme for cumulus parameterization in large-scale models, Mon. Weather Rev., 117, 1779-1800, 1989.

Tompkins, A. M.: Organization of tropical convection in low vertical wind shears: The role of cold pools, J. Atmos. Sci., 58, 16501672, 2001.

Torri, G. and Kuang, Z.: A Lagrangian study of precipitation-driven downdrafts, J. Atmos. Sci., 73, 839-854, 2016.

Wakimoto, R. M.: The life cycle of thunderstorm gust fronts as viewed with Doppler radar and rawinsonde data, Mon. Weather Rev., 110, 1060-1082, 1982.
Wang, H. and Feingold, G.: Modeling mesoscale cellular structures and drizzle in marine stratocumulus. Part I: Impact of drizzle on the formation and evolution of open cells, J. Atmos. Sci., 66, 3237-3256, 2009.

Wang, J., Krejci, R., Giangrande, S., Kuang, C., Barbosa, H. M., Brito, J., Carbone, S., Chi, X., Comstock, J., Ditas, F., and Lavric, J.: Amazon boundary layer aerosol concentration sustained by vertical transport during rainfall, Nature, 539, 416-419, 2016.

Weisman, M. L. and Klemp, J. B.: Characteristics of isolated convective storms, in: Mesoscale Meteorology and Forecasting, American Meteorological Society, 331-358, 1986.

Wilson, J. W. and Schreiber, W. E.: Initiation of convective storms at radar-observed boundary-layer convergence lines, Mon. Weather Rev., 114, 2516-2536, 1986.

Zhang, G. J. and McFarlane, N. A.: Sensitivity of climate simulations to the parameterization of cumulus convection in the Canadian Climate Centre general circulation model, Atmos. Ocean, 33, 407-446, 1995.

Zipser, E. J.: The role of organized unsaturated convective downdrafts in the structure and rapid decay of an equatorial disturbance, J. Appl. Meteorol., 8, 799-814, 1969.

Zipser, E. J.: Mesoscale and convective-scale downdrafts as distinct components of squall-line structure, Mon. Weather Rev., 105, 1568-1589, 1977.

Zuidema, P., Li, Z., Hill, R. J., Bariteau, L., Rilling, B., Fairall, C., Brewer, W. A., Albrecht, B., and Hare, J.: On trade wind cumulus cold pools, J. Atmos. Sci., 69, 258-280, 2012. 